Article

\title{
Inter- and Intra-Individual Variation in the Behavior of Feed Intake on Nutrient Availability in Early Lactating Dairy Cows
}

\author{
Theresa Rumphorst ${ }^{1, *(1)}$, Theresa Scheu ${ }^{2}$, Christian Koch ${ }^{2}(\mathbb{D})$ and Albert Sundrum ${ }^{1, *}$ \\ 1 Department of Animal Nutrition and Animal Health, Faculty of Organic Agricultural Sciences, \\ University of Kassel, Nordbahnhofstr. 1a, 37213 Witzenhausen, Germany \\ 2 Educational and Research Centre for Animal Husbandry, Hofgut Neumuehle, 67728 Muenchweiler an der \\ Alsenz, Germany; t.scheu@neumuehle.bv-pfalz.de (T.S.); c.koch@neumuehle.bv-pfalz.de (C.K.) \\ * Correspondence: theresa.rumphorst@gmx.de (T.R.); sundrum@uni-kassel.de (A.S.); \\ Tel.: +49-151-75036558 (T.R.)
}

Citation: Rumphorst, T.; Scheu, T.; Koch, C.; Sundrum, A. Inter- and Intra-Individual Variation in the Behavior of Feed Intake on Nutrient Availability in Early Lactating Dairy Cows. Animals 2022, 12, 37. https:// doi.org/10.3390/ani12010037

Academic Editor: Marina Von Keyserlingk

Received: 28 November 2021 Accepted: 22 December 2021 Published: 24 December 2021

Publisher's Note: MDPI stays neutral with regard to jurisdictional claims in published maps and institutional affiliations.

Copyright: (C) 2021 by the authors. Licensee MDPI, Basel, Switzerland. This article is an open access article distributed under the terms and conditions of the Creative Commons Attribution (CC BY) license (https:// creativecommons.org/licenses/by/ $4.0 /)$.
Simple Summary: The problem of nutrient and energy deficiency and the associated risk of disease in fresh dairy cows has been known for many years. Previous approaches to reducing the risk have been almost exclusively on a herd basis approach but have so far not been sufficiently effective. The present study revealed large variation between individual animals during the first weeks after calving, particularly with respect to dry matter intake (DMI). In addition to the large variation in intake behavior, feed intake and nutrient digestibility, interactions between parameters refute the traditional feeding regimes, based on the mean requirement values at herd level. Inter-individual variation indicates that each animal follows an individual strategy in optimizing DMI. Only if constant access to the feed bunk and balanced diets are made possible, all animals can follow their individual strategy, maximize individual DMI and come closer to the goal of an adequate supply. As there is only a low risk for excessive DMI during early lactation, feeding regimes should not be oriented towards the assumed average level of feed intake but towards the animals with a low level of dry matter intake. Otherwise, it will not be possible to improve the nutrient supply for all animals.

\begin{abstract}
Since energetic deficits in dairy cows can only be reduced at an animal level, the objective of the present study was to determine the extent of variation in intake behavior within and between animals during early lactation, to explore the magnitude of interactions between feed intake, intake behavior and nutrient digestibility, and to identify levers for maximizing feed intake at the individual animal level. Feeding behavior, intake and nutrient digestibility of 28 German Holstein dairy cows, fed TMR with 7.0 MJ NEL, were studied between the 2nd and 15th week after calving. Dry matter intake was assessed daily and nutrient digestibility weekly, with $\mathrm{iNDF}_{240}$ as an intrinsic marker. Results showed high intra- and inter-individual variation in intake behavior parameters with coefficients of variation (CV) up to 0.58 in meal frequency. Nutrient digestibility varied only slightly with CV values up to 0.10 in crude protein. Milk yield, meal frequency, feeding time, feeding rate and meal size had significant positive effects on DMI $(p<0.01)$. To achieve long-term improvements in feed intake, it is important to optimize feed intake and feeding behavior of individual animals by improving feeding conditions and develop technical tools to identify animals with insufficient feed intake.
\end{abstract}

Keywords: dairy cows; variation; digestibility; dry matter intake; intake behavior; nutrient availability

\section{Introduction}

Many high-yielding dairy cows suffer severe nutrient and energy deficits in early lactation [1,2]. These deficient states stress body functions and reduce an animal's resistance to stressors while increasing the risk of metabolic and infectious diseases [3-5]. Especially in early lactation, many factors affect the performance and health status of dairy cows, but the level of influence can vary between individual animals (Figure 1). 


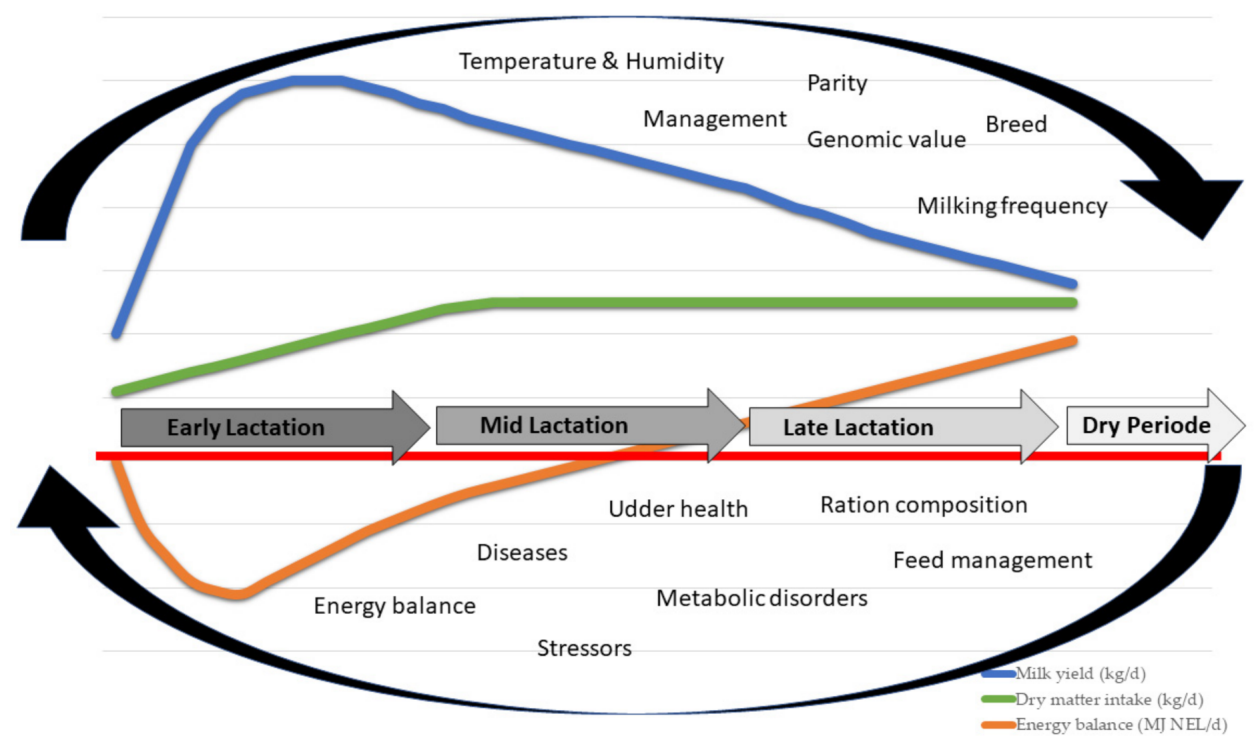

Figure 1. Schematic representation of factors affecting milk yield, dry matter intake and energy balance of dairy cows during different states of lactation [6].

The magnitude of nutrient and energy deficiencies also varies between dairy cows and depends on nutrient and energy intake and requirements. In addition, there is a large variation between individual cows in their ability to cope with metabolic imbalance [2]. The individual availability of nutrients and energy results from the combination of feed components in the diet, the level of feed intake and the degree of digestibility of the feed in an animal, as well as the variation and interaction within and between these factors. Of these factors, feed intake has proportionately the greatest impact on the level of nutrient and energy availability. Accordingly, research in recent years has focused on optimizing diet composition in relation to the average requirements of the dairy cows in the feeding group to achieve a high level of dry matter intake (DMI) [7-9]. While feeding behavior showed a considerable effect on the level of DMI [10,11], it is often not adequately considered in ration calculation, feeding management or nutrient supply. In addition, it is difficult to assess feeding behavior in practice. Feeding behavior can be described by the number, duration and size of individual meals per day [12]. DMI, as the sum of single meals, is influenced both positively and negatively by the individual behavior patterns as well as their interactions [10]. Furthermore, an influence on the digestibility of the ingested diet has also been described. Baumont et al. [13] and Golden et al. [14] revealed that cattle and small ruminants which ate smaller and more frequent meals showed higher nutrient digestibility than animals that ate less frequent, but larger, meals. Tyrrell and Moe [15] and Potts et al. [16] found that digestibility diminished with increasing feed intake. Higher feed intake results in a higher passage rate, which leads to a reduced digestion time. However, the extent of variation among individual animals and the degree of antagonistic relationships between feeding behavior, feed intake and digestibility have so far received little attention. Since individual deficiencies can only be reduced at the animal level, the objective of the present study was to determine the extent to which intake behavior and nutrient digestibility varies within and between animals during early lactation, to explore the extent of interactions between feed intake, intake behavior and nutrient digestibility, and to identify levers for maximizing feed intake and hence nutrient intake at an individual animal level.

\section{Materials and Methods}

All procedures described in this study were performed according to the German Animal Welfare Act and approved by the local authority for animal welfare affairs (Landesuntersuchungsamt Rheinland-Pfalz; G 18-20-073) in Koblenz, Germany. 


\subsection{Animal Housing and Diet}

The study was carried out between April and October 2018 at the Educational and Research Centre for Animal Husbandry, Hofgut Neumuehle, Muenchweiler a.d. Alsenz, Germany. A total of 28 German Holstein dairy cows ranging from the 2 nd to 8 th parity (mean $=2.9 ; \mathrm{SD}=1.3$ ) and between the 2 nd and 15 th week of lactation were used. German Holsteins are the most common dairy breed in Germany and play a crucial role in the German dairy industry. Parity and mean daily milk yield $(\mathrm{kg} / \mathrm{d})$ of every single cow during the course of study were shown in Table 1.

Table 1. Parity and mean daily milk yield $(\mathrm{kg} / \mathrm{d})$ of the trial cows between the 2 nd and 15 th week of lactation.

\begin{tabular}{ccc}
\hline Animal & Parity & Mean Daily Milk Yield (kg/d) \\
\hline 825 & 8 & 50.3 \\
1208 & 5 & 40.5 \\
1252 & 4 & 49.0 \\
1274 & 4 & 47.0 \\
1309 & 4 & 48.2 \\
1321 & 4 & 44.9 \\
1326 & 4 & 51.4 \\
1332 & 4 & 42.2 \\
1401 & 3 & 49.4 \\
1416 & 3 & 46.6 \\
1419 & 3 & 46.5 \\
1428 & 3 & 45.4 \\
1434 & 3 & 34.4 \\
1440 & 3 & 51.6 \\
1450 & 2 & 43.5 \\
1457 & 2 & 55.5 \\
1460 & 2 & 51.4 \\
1510 & 2 & 41.3 \\
1515 & 2 & 47.4 \\
1522 & 2 & 43.5 \\
1523 & 2 & 38.5 \\
1524 & 2 & 44.0 \\
1525 & 2 & 52.1 \\
1533 & 2 & 41.7 \\
1536 & 2 & 44.6 \\
1537 & 2 & 40.4 \\
1540 & 2 & 35.7 \\
1563 & & 50.0 \\
\hline & &
\end{tabular}

The cows were housed together with non-experimental cows in a free-stall barn with 60 cubicles and 30 feeding units. Cows had unlimited access to fresh water and were fed a total mixed ration (TMR) ad libitum (Table 2). The TMR was prepared in the morning and delivered twice daily (60\% of total daily amount at 6 a.m. and $40 \%$ of total daily amount at 11 a.m.).

\subsection{Data and Sample Collection}

Individual feed intake was measured daily with the Insentec B.V. (Marknesse, the Netherlands) RIC (roughage intake control) automatic weighing system. Cows were identified using individual collar transponders, which registered access to the feeding unit. The connected computer recorded cow number, feeder number, trough weight and the time of the beginning and the end of each visit. TMR intake per visit was calculated from the differences in trough weight between start and end of the visit. Feeding time was calculated from the difference between start and end timepoint. Each visit resulting in a trough weight difference of more than $0.1 \mathrm{~kg}$ was considered a meal. All parameters 
were calculated on a dry matter base by multiplying the amount of fresh matter by the dry matter (DM) content of the TMR. Intake behavior was characterized for an individual animal over a day by the following parameters and definitions, according to Nielsen [12]: meal frequency (meals/d), defined as number of individual feeding bouts per day; meal duration ( $\mathrm{min} / \mathrm{meal})$, defined as average time per meal, average meal size $(\mathrm{kg} \mathrm{DM} / \mathrm{meal})$; daily feeding time ( $\mathrm{min} / \mathrm{d})$, defined as the sum of the meal durations in a day; daily DMI $(\mathrm{kg} \mathrm{DM} / \mathrm{d})$, defined as the sum of the meal sizes in a day and speed of food ingested; or feeding rate $(\mathrm{g} \mathrm{DM} / \mathrm{min})$, defined as the ratio between meals size $(\mathrm{kg} \mathrm{DM} /$ meal) and meal duration ( $\mathrm{min} / \mathrm{meal}$ ). To account for the individuality of feed intake behavior, the general term "feeding behavior" is replaced by the term "intake behavior" in all that follows. The individual parameters of daily intake behavior were averaged for every cow per week of lactation. Cows were milked twice daily between 5.00 and 7.30 a.m. and between 3.30 and 6.00 p.m. The daily milk yield was recorded electronically via the herd management system Dairy Plan C21 (GEA Farm Technologies, Boenen, Germany). Milk aliquots from one evening and the next morning were taken biweekly and pooled for further analysis of milk fat, protein and lactose by infrared spectrophotometry using a MilkoScan FT6000 (Foss Analytical A/S, Hillerød, Denmark). TMR samples were taken daily within one hour of feed delivery. Daily samples were combined on a weekly basis with a representative TMR sample of $800-1000 \mathrm{~g}$ for determining the weekly dry matter content. Starting at the day of calving, individual cow fecal samples were collected weekly two hours after morning milking via rectal palpation. The samples were labeled and stored frozen at $-20^{\circ} \mathrm{C}$ until chemical analysis. Deviations in fecal content within a day, especially in aNDFom and $\mathrm{iNDF}_{240}$, were reduced by defining a fixed time of feeding and sampling, which remained constant over the test period.

Table 2. Ingredient, chemical composition and energy content of the total mixed ration.

\begin{tabular}{|c|c|c|}
\hline Diet Composition (g/kg DM) ${ }^{1}$ & Mean & SD \\
\hline Beet pressed pulp silage & 188.3 & \\
\hline Grass silage & 97.0 & \\
\hline Grass hay & 74.7 & \\
\hline Maize silage & 259.6 & \\
\hline Concentrate & 380.4 & \\
\hline \multicolumn{3}{|l|}{ Chemical Composition (g/kg DM) ${ }^{1}$} \\
\hline Dry matter & 402.0 & 13.8 \\
\hline $\mathrm{OM}$ & 931.4 & 3.8 \\
\hline $\mathrm{CP}$ & 157.4 & 8.1 \\
\hline SP & 63.2 & 7.3 \\
\hline $\mathrm{EE}$ & 43.0 & 2.4 \\
\hline aNDFom & 355.1 & 8.8 \\
\hline $\mathrm{ADF}$ & 219.3 & 4.9 \\
\hline Lignin & 28.3 & 1.2 \\
\hline $\mathrm{iNDF}_{240}$ & 86.4 & 4.5 \\
\hline Starch & 182.3 & 14.8 \\
\hline ESC & 63.1 & 3.4 \\
\hline $\mathrm{TDN}^{2}$ & 732.0 & 5.0 \\
\hline \multicolumn{3}{|l|}{ Energy (MJ/kg DM) } \\
\hline $\mathrm{NE}_{\mathrm{L}}{ }^{3}$ & 7.0 & 0.0 \\
\hline
\end{tabular}

${ }^{1}$ Diet and chemical composition reported on $105^{\circ} \mathrm{C}$ dry matter. Averaged values based on weekly conducted feed analysis; diet was offered as TMR. ADF-acid detergent fiber, expressed inclusive of residual ash; aNDFomneutral detergent fiber assayed with heat-stable amylase and expressed exclusive of residual ash; $\mathrm{CP}-\mathrm{crude}$ protein; $\mathrm{CV}$ - coefficient of variation calculated as ratio of standard deviation to mean; EE - ether extract; ESC ethanol-soluble carbohydrates; $\mathrm{iNDF}_{240}$ —indigestible aNDFom; OM—organic matter; SD—standard deviation; $\mathrm{SP}$-soluble protein. ${ }^{2} \mathrm{TDN}(\mathrm{g} / \mathrm{kg})$ - total digestibly nutrient values for TMR samples were calculated from the TDN value using Equations (2)-(5) by [17]. ${ }^{3} \mathrm{NE}_{\mathrm{L}}$-net energy for lactation, for TMR samples were calculated from the TDN value using Equations (2)-(3) by [17]. 


\subsection{Chemical Analysis}

Dry matter content was determined in a two-step process: thawed TMR and feces samples were first oven dried at $60^{\circ} \mathrm{C}$ for $48 \mathrm{~h}$ and ground to $1 \mathrm{~mm}$ particles, followed by drying at $105^{\circ} \mathrm{C}$ for $3 \mathrm{~h}$ until constant weight was achieved. Organic matter (OM) was measured by ashing $\left(550^{\circ} \mathrm{C}\right)$ overnight. The dried and ground samples were submitted to Cumberland Valley Analytical Services Inc., Waynesboro, PA (CVAS), for chemical analysis. All TMR samples were analyzed for dry matter (DM), organic matter (OM) (method 942.05; [18]), crude protein (CP) (method 990.03; [18]), soluble protein (SP) [19], ether extract (EE) (method 2003.05; [18]), neutral detergent fiber assayed with heat-stable amylase and expressed exclusive of residual ash (aNDFom) [20], acid detergent fiber (ADF), expressed inclusive of residual ash (method 978.10; [18]), lignin (method 973.18; [18]), ethanol-soluble carbohydrates (ESC) [21], starch [22] and $240 \mathrm{~h}$ in vitro indigestible neutral detergent fiber $\left(\mathrm{iNDF}_{240}\right)$ [23]. Dried and ground fecal samples were split into two subsamples. One subsample was analyzed with near infrared reflectance spectroscopy (NIRS) described by [24]. The analysis included DM, OM and CP. The other subsample was submitted to CVAS for determination of ADF, aNDFom and $\mathrm{iNDF}_{240}$.

\subsection{Calculations and Statistical Analysis}

Sample size was determined by the capacity of the research facility. Our sample size of $\mathrm{n}=28$ was assumed as adequate to reliably detect differences between cows and weeks of lactation ( $>0.95$ statistical power and $p \leq 0.05$ significance level; $G^{*}$ power 3 software; [25]). Organic matter digestibility (OMD), crude protein digestibility (CPD), neutral detergent fiber digestibility (NDFD) and acid detergent digestibility (ADFD) were calculated from iNDF 240 as internal marker and nutrient concentrations in TMR and feces using the following equation, by [26]:

Apparent nutrient digestibility $(\mathrm{g} / \mathrm{kg})=1000-100 \times\left\{\left[\mathrm{iNDF}_{240}\right]\right.$ Diet/[iNDF 240$]$ Feces $\} \times\{[$ nutrient $]$ Feces/[nutrient $]$ Diet $\}$

Data was analyzed using the SPSS 25.0 software (IBM Company Inc., Chicago, IL, USA). Each variable was checked for normal distribution by a histogram and a Q-Q plot, and the mean, range, standard deviation (SD) and coefficient of variation (CV) were calculated. Differences were considered significant at a level of $p \leq 0.05$, and a tendency was considered at $0.05<p \leq 0.10$. Changes of each parameter for all cows over the course of the study are shown by box plots, which represent the median, interquartile range and extreme cases of individual variables.

The differences in intake behavior and nutrient digestibility across the trial period were analyzed using the GLM repeated measures procedure. When Mauchly's test indicated that the assumption of sphericity had been violated, the degrees of freedom were corrected using Greenhouse-Geisser estimates if the estimate was lower than 0.75 , or the Huynh-Feld estimate if the estimate was greater than 0.75 [27]. The effect sizes for main effects and interactions were determined by partial eta squared $\left(\eta^{2}\right)$ values. Partial eta squared $\left(\eta^{2}\right)$ values were classified as small (0.01 to 0.059$)$, moderate (0.06 to 0.137$)$ and large $(>0.137)$.

Differences in intake behavior between second and greater than or equal to third lactating dairy cows were analyzed using an independent samples $t$-test.

The effects of intake behavior on DMI and on the four measured variables (nutrient digestibility of $\mathrm{OM}, \mathrm{CP}, \mathrm{NDF}$ and $\mathrm{ADF}$ ) were statistically tested using the linear mixed model (LMM) procedure. Analyses were carried out on the individual animal as the observational unit. Akaike's information criterion and relative standard error (RSE) were, respectively, used for model evaluation and to find the best-fit model. Correlations, calculated with Pearson correlation coefficient, between dependent variables were low $(\mathrm{R}<0.80$; [28]), indicating that multicollinearity was not a confounding factor in the analysis. The final model to test the effect of intake behavior on DMI included the fixed effects of milk yield, meal frequency, feeding time, meal size, feeding rate and a random intercept for the cow. Meal duration $(\mathrm{min} / \mathrm{meal})$ was used to calculate feeding time $(\mathrm{min} / \mathrm{d})$ and feeding rate $(\mathrm{g} / \mathrm{min})$ and was therefore excluded. There were no significant two-way interaction terms between 
the fixed effects. The final model to test the effect of intake behavior on nutrient digestibility of OM, CP, NDF and ADF included the fixed effects of week of lactation, DMI (kg/day), meal frequency (meals $/ \mathrm{d})$, feeding time $(\mathrm{min} / \mathrm{d})$, meal size $(\mathrm{kg} /$ meal $)$, feeding rate $(\mathrm{g} / \mathrm{min})$ and a random intercept for the cow. There were no significant two-way interaction terms between the fixed effects. Meal duration ( $\mathrm{min} / \mathrm{meal}$ ) was used to calculate feeding time $(\mathrm{min} / \mathrm{d})$ and feeding rate $(\mathrm{g} / \mathrm{min})$ and was therefore excluded from both calculations.

Cows were retrospectively grouped in quartiles based on average DMI between week 2 and 15 of lactation. The use of quartiles in the formation of groups has the advantage of providing greater differentiation between cows having high differences in DMI. The three groups were created based on the mean DMI of the cows during the trial period. The first group was the lower quartile, consisting of the cows with the lowest mean DMI $(<18.99 \mathrm{~kg}$ $\mathrm{DMI} / \mathrm{d}, \mathrm{n}=7$ ) between week 2 and 15 of lactation. The second and third groups consisted of the intermediate (between 19.00 and $20.93 \mathrm{~kg} \mathrm{DMI} / \mathrm{d}, \mathrm{n}=14)$ and upper $(>20.94 \mathrm{~kg} \mathrm{DMI} / \mathrm{d}$, $\mathrm{n}=7$ ) quartiles, respectively. Differences in intake behavior and nutrient digestibility were analyzed using ANOVA, with quartiles as fixed factor. The individual quartile comparisons were performed using post hoc pair-wise comparisons, with the Sidak correction applied.

\section{Results}

\subsection{Interactions between Intake Behaviour and DMI during Early Lactation}

The trends of intake behavior parameters and feed intake over the course of the study are shown in Figure 2. DMI significantly increased with a linear $\left(p<0.001 ; \eta^{2}=0.75\right)$ and quadratic $\left(p<0.001 ; \eta^{2}=0.677\right)$ trend from a mean value of $14.3 \pm 2.3 \mathrm{~kg}$ DMI per day in week 2 up to $22.1 \pm 2.3 \mathrm{~kg}$ in week 11 and $21.57 \pm 2.3 \mathrm{~kg}$ in week 15 (Figure 2a). Mean CV of DMI ranged between 0.09 (week 9) and 0.17 (week 3). Daily meal frequency remained at the same level of $23.6 \pm 11.5$ meals over the course of study $\left(p>0.005 ; \eta^{2}=0.122\right.$; Figure $\left.2 b\right)$. Mean CV of daily meal frequency was lowest in week $3(0.39)$ and highest in week $14(0.58)$. Meal duration had a mean of $9.9 \pm 4.0 \mathrm{~min} / \mathrm{meal}$ and constantly increased with a linear $\left(p<0.001 ; \eta^{2}=0.572\right)$ and quadratic $\left(p<0.001 ; \eta^{2}=0.223\right)$ trend from $7.4 \mathrm{~min} / \mathrm{meal}$ in week 2 p.p. to $11.9 \mathrm{~min} / \mathrm{meal}$ in week 11 p.p. (Figure 2c). CV values ranged from 0.35 (week 14 ) to 0.45 (week 10). Feeding time per day increased significantly $\left(p<0.001 ; \eta^{2}=0.298\right)$ with a linear $\left(p<0.05 ; \eta^{2}=0.385\right)$ and quadratic $\left(p<0.001 ; \eta^{2}=0.606\right)$ trend from a mean value of $151.2 \pm 31.6 \mathrm{~min}$ per day in week 2 up to $228.9 \pm 48.8 \mathrm{~min}$ per day in week 10 , and constantly decreased to a value of $209.1 \pm 49.8 \mathrm{~min}$ in week 15 p.p. (Figure $2 \mathrm{~d}$ ). CV values of total feeding time per day ranged between 0.19 (week 11) and 0.24 (week 7). The meal size had a mean of $0.96 \pm 0.4 \mathrm{~kg} /$ meal and constantly increased with a linear $\left(p<0.001 ; \eta^{2}=0.602\right)$ trend between week 2 and 15 of lactation from $0.7 \pm 0.3 \mathrm{~kg} / \mathrm{meal}$ to $1.3 \pm 0.6 \mathrm{~kg} /$ meal, respectively $\left(p<0.001 ; \eta^{2}=0.602\right.$; Figure $\left.2 \mathrm{e}\right)$, with $C V$ values between 0.35 (week 13) and 0.46 (weeks 8 and 15). The feeding rate remained at the same level of $93.41 \pm 22.7$ g per min up to week 15 p.p. $\left(p>0.005 ; \eta^{2}=0.122\right.$; Figure $\left.2 \mathrm{f}\right)$ and $\mathrm{CV}$ ranged between 0.21 (week 13) and 0.30 (week 3).

The LMM showed significant positive effects of milk yield, meal frequency, feeding time, feeding rate and a comparable high effect of meal size on daily DMI of dairy cows (Table 3).

Table 4 illustrates the mean, SD and CV of DMI and variables of intake behavior for second and greater than or equal to third lactating dairy cows. Mean DMI and SD of meal frequency were significant lower in second lactating cow $(p=0.043 ; p=0.021)$. No other significant differences were detected between parity groups.

In addition to the high variation in intake behavior between dairy cows at the same stage of lactation, the extent of variation in intake behavior during early lactation within individual animals was also great (Figure 3). Intra-individual CVs of DMI ranged between 0.05 and 0.25 , CVs of meal frequency ranged between 0.11 and 0.36 . For meal duration and feeding time, CVs ranged between 0.10 and 0.36 and between 0.08 and 0.26 , respectively. The widest range in CVs was detected for meal size (0.1-0.42). Intra-individual CVs for feeding rate ranged between 0.07 and 0.30 . 


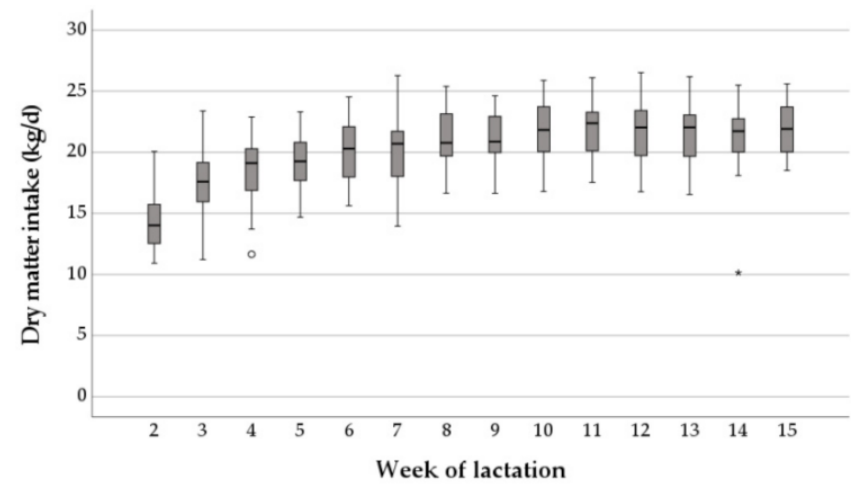

(a)

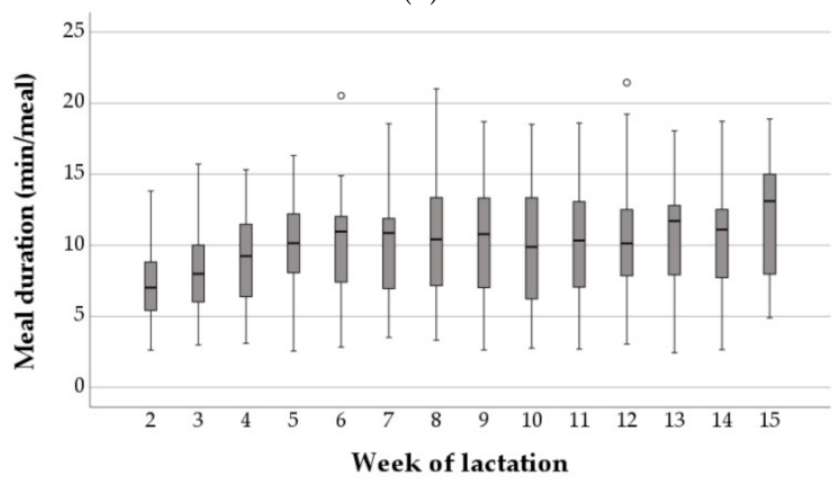

(c)

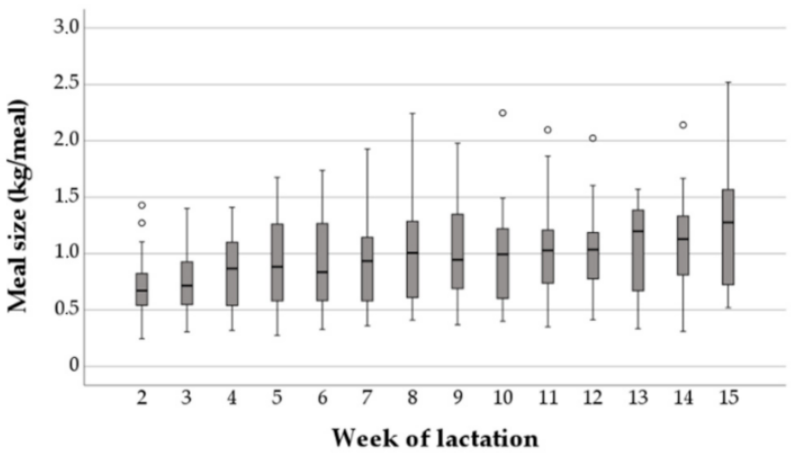

(e)

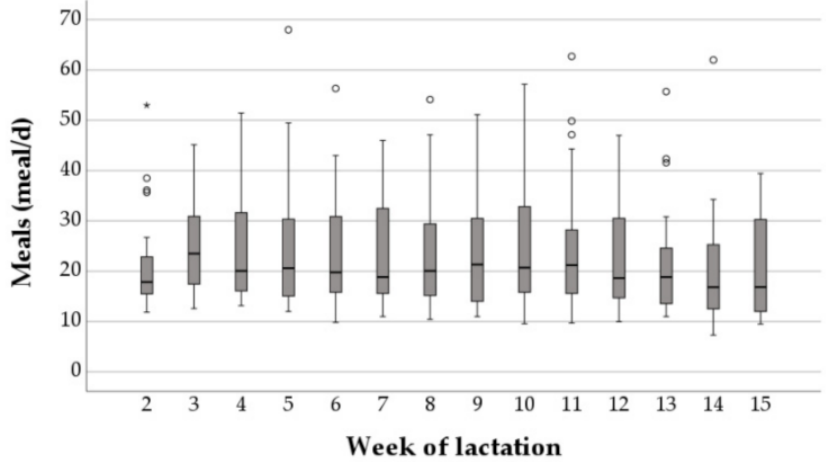

(b)

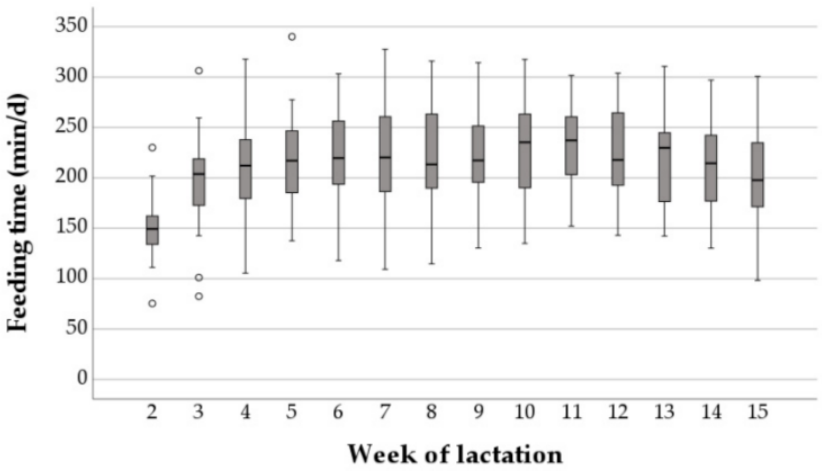

(d)

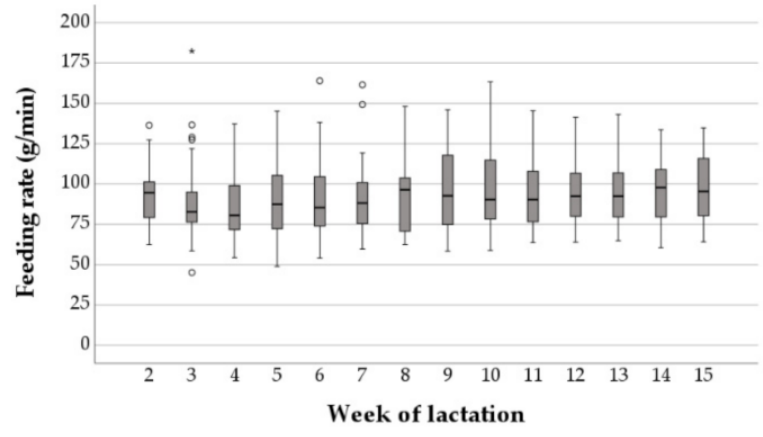

(f)

Figure 2. Dry matter intake (kg/day) (a), meal frequency (meals/d) (b), meal duration (min/meal) (c), feeding time $(\mathrm{min} / \mathrm{d})(\mathbf{d})$, meal size $(\mathrm{kg} / \mathrm{meal})(\mathbf{e})$ and feeding rate $(\mathrm{g} / \mathrm{min})(\mathbf{f})$, measured for all 28 cows between week 2 and 15 postpartum (p.p.). In each subfigure, the boxplots highlight, respectively, the median and upper and lower quartiles of each week. Small circles = outliers $(1.5 \times$ interquartile range $(\mathrm{IQR}))$; asterisks $=$ extreme values $(3 \times \mathrm{IQR})$. 
Table 3. Influence of milk yield and intake behavior on dry matter intake during early lactation in dairy cows, estimated by the linear mixed model $(\mathrm{LMM})$ procedure $(\mathrm{n}=28)$.

\begin{tabular}{cccc}
\hline & \multicolumn{3}{c}{ Daily DMI $^{\mathbf{1}}$ (kg/Day) } \\
\hline Parameter & $\mathbf{b}^{\mathbf{2}}$ & $\mathbf{S E}$ & $p$-Value \\
\hline Intercept & -7.60 & 1.02 & $<0.01$ \\
Milk yield (kg/d) & 0.12 & 0.02 & $<0.01$ \\
Meal frequency (meals/d) & 0.11 & 0.02 & $<0.01$ \\
Meal size (kg DM/meal) & 4.89 & 0.41 & $<0.01$ \\
\hline Feeding time (min/d) & 0.05 & 0.00 & $<0.01$ \\
\hline Feeding rate (g/min) & 0.05 & 0.00 & \\
\hline AIC $^{3}$ & 1322.59 & & \\
\hline
\end{tabular}

${ }^{1}$ Dry matter intake. ${ }^{2}$ Parameter estimate. ${ }^{3}$ Akaike's information criterion.

Table 4. Mean, SD and CV values of dry matter intake (DMI) and variable of intake behavior of early lactating dairy cows grouped in second and greater than or equal to third lactating dairy cows.

\begin{tabular}{|c|c|c|c|c|}
\hline & & \multicolumn{2}{|c|}{ Parity } & \multirow[b]{2}{*}{$p$-Value } \\
\hline & & 2 & $\geq 3$ & \\
\hline \multirow{3}{*}{$\mathrm{DMI}^{1}(\mathrm{~kg} / \mathrm{d})$} & mean & 19.9 & 20.3 & 0.043 \\
\hline & SD & 3.4 & 3.0 & 0.375 \\
\hline & $\mathrm{CV}$ & 0.2 & 0.1 & 0.301 \\
\hline \multirow{3}{*}{$\begin{array}{l}\text { Meal frequency } \\
\quad(\text { meals } / \mathrm{d})\end{array}$} & mean & 21.6 & 25.7 & 0.112 \\
\hline & SD & 9.0 & 13.3 & 0.021 \\
\hline & $\mathrm{CV}$ & 0.4 & 0.5 & 0.427 \\
\hline \multirow{3}{*}{$\begin{array}{l}\text { Meal duration } \\
(\mathrm{min} / \mathrm{meal})\end{array}$} & mean & 10.6 & 9.4 & 0.581 \\
\hline & SD & 3.7 & 4.3 & 0.493 \\
\hline & $\mathrm{CV}$ & 0.3 & 0.5 & 0.934 \\
\hline \multirow{3}{*}{$\begin{array}{l}\text { Feeding time } \\
\quad(\min / \mathrm{d})\end{array}$} & mean & 222.5 & 204.3 & 0.776 \\
\hline & SD & 50.4 & 46.4 & 0.056 \\
\hline & $\mathrm{CV}$ & 0.2 & 0.2 & 0.251 \\
\hline \multirow{3}{*}{$\begin{array}{l}\text { Meal size } \\
(\mathrm{g} / \mathrm{meal})\end{array}$} & mean & 1.0 & 0.9 & 0.753 \\
\hline & $\mathrm{SD}$ & 0.5 & 0.4 & 0.984 \\
\hline & $\mathrm{CV}$ & 0.5 & 0.4 & 0.412 \\
\hline \multirow{3}{*}{$\begin{array}{l}\text { Feeding rate } \\
\qquad(\mathrm{g} / \mathrm{min})\end{array}$} & mean & 86.9 & 99.9 & 0.668 \\
\hline & $\mathrm{SD}$ & 21.5 & 22.1 & 0.476 \\
\hline & $\mathrm{CV}$ & 0.2 & 0.2 & 0.324 \\
\hline
\end{tabular}

${ }^{1}$ Dry matter intake. 


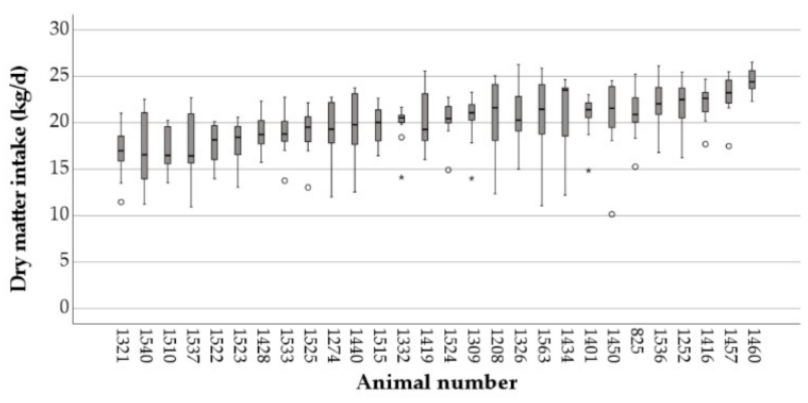

(a)

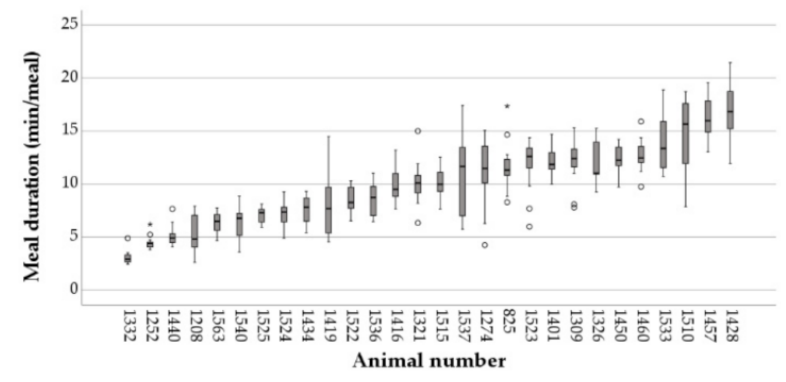

(c)

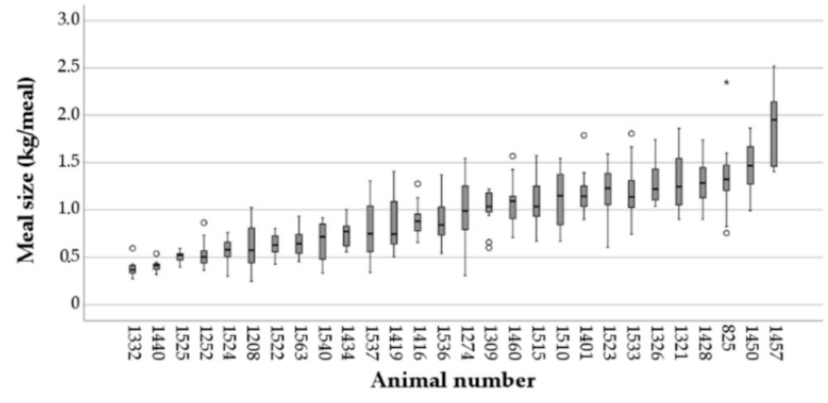

(e)

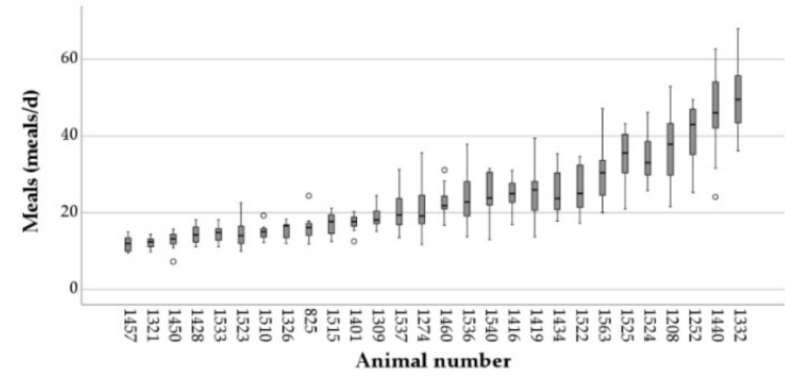

(b)

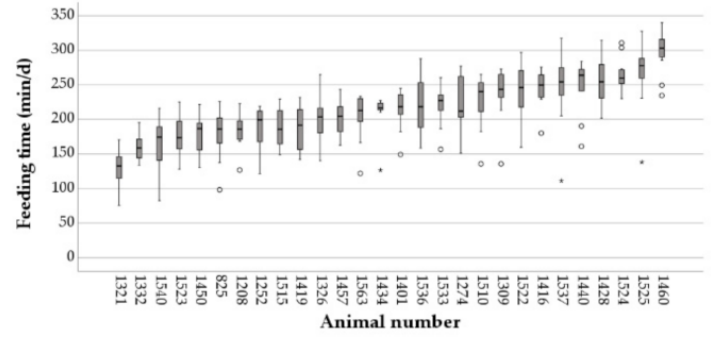

(d)

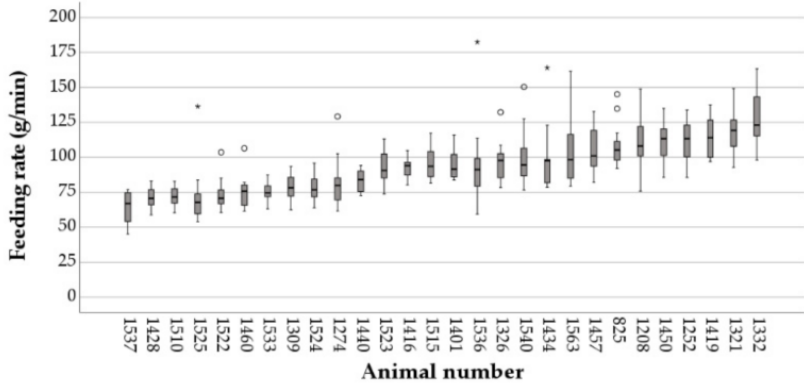

(f)

Figure 3. Dry matter intake (kg/day) (a), meal frequency (meals/d) (b), meal duration (min/meal) (c), feeding time $(\mathrm{min} / \mathrm{d})(\mathbf{d})$, meal size $(\mathrm{kg} / \mathrm{meal})(\mathbf{e})$ and feeding rate $(\mathrm{g} / \mathrm{min})(\mathbf{f})$, measured for individual animals $(n=28)$ between week 2 and 15 postpartum (p.p.). In each subfigure, the boxplots highlight, respectively, the median and upper and lower quartiles of each week. Small circles $=$ outliers $(1.5 \times$ interquartile range $(\mathrm{IQR}))$; asterisks $=$ extreme values $(3 \times \mathrm{IQR})$.

When comparing mean and CV values of intake behavior parameters of cows with mean low, medium and high DMI, no significant differences could be detected between the quartiles (Table 5). 
Table 5. Mean and CV values of DMI and intake behavior of early lactating dairy cows grouped in quartiles according to mean DMI observed between week 2 and 15 of lactation.

\begin{tabular}{ccccc}
\hline & $\begin{array}{c}\text { Lower Quartile } \\
(<\mathbf{2 5} \mathbf{0})\end{array}$ & $\begin{array}{c}\text { Intermediate } \\
\text { Quartile }\end{array}$ & $\begin{array}{c}\text { Upper Quartile } \\
\mathbf{( > 7 5 \% )}\end{array}$ & $p$-Value \\
\hline Mean DMI $^{1}$ & 17.61 & 20.14 & 22.30 & $>0.05$ \\
CV DMI $^{1}$ & 0.15 & 0.14 & 0.10 & $>0.05$ \\
Mean meal frequency & 18.24 & 27.62 & 21.83 & $>0.05$ \\
CV meal frequency & 0.19 & 0.21 & 0.19 & $>0.05$ \\
Mean meal duration & 11.35 & 8.67 & 10.85 & $>0.05$ \\
CV meal duration & 0.22 & 0.20 & 0.15 & $>0.05$ \\
Mean feeding time & 206.61 & 215.51 & 216.24 & $>0.05$ \\
CV feeding time & 0.18 & 0.14 & 0.14 & $>0.05$ \\
Mean meal size & 1.00 & 0.82 & 1.16 & $>0.05$ \\
CV meal size & 0.26 & 0.23 & 0.22 & $>0.05$ \\
Mean feeding rate & 0.08 & 0.10 & 0.10 & $>0.05$ \\
CV feeding rate & 0.14 & 0.16 & 0.16 & $>0.05$ \\
\hline
\end{tabular}

${ }^{1}$ Dry matter intake.

\subsection{Interactions between Intake Behavior and Nutrient Digestibility during Early Lactation}

The highest mean value regarding the nutrient digestibility of the diet was found for $\mathrm{OM}(728.8 \pm 19.8 \mathrm{~g} / \mathrm{kg})$, followed by CP, NDF and ADF with $625.4 \pm 50.7,585.1 \pm 43.5$ and $571.9 \pm 34.3 \mathrm{~g} / \mathrm{kg}$, respectively. Over the course of the study, mean CV was highest for $\mathrm{CP}$ with a value of $0.08(0.06-0.10)$ followed by NDF, ADF and OM with $0.07(0.05-0.10)$, $0.06(0.05-0.07)$ and $0.03(0.02-0.03)$, respectively.

The GLM repeated measures procedure reported significant differences between week of lactation for CP $\left(p=0.032 ; \eta^{2}=0.164\right)$ and NDF digestibility $\left(p=0.00 ; \eta^{2}=0.427\right)$ with a quadratic trend over the time for $\mathrm{CP}\left(p=0.041 ; \eta^{2}=0.212\right)$ and $\operatorname{NDF}\left(p=0.039 ; \eta^{2}=0.215\right)$. CP digestibility decreased from $653.4 \pm 46.9 \mathrm{~g} / \mathrm{kg}$ in week 2 to $618.6 \pm 60.9 \mathrm{~g} / \mathrm{kg}$ in week 9 , and increased again up to $634.1 \pm 48.8 \mathrm{~g} / \mathrm{kg}$ in week 15 . NDF digestibility decreased from $607.4 \pm 54.0 \mathrm{~g} / \mathrm{kg}$ in week 2 to $577.0 \pm 36.4 \mathrm{~g} / \mathrm{kg}$ in week 10 and increased again up to $58.5 .4 \pm 49.3 \mathrm{~g} / \mathrm{kg}$ in week 15 . No significant differences between the weeks of lactation for OM and ADF digestibility were detected. Variation in OMD within individual animals during early lactation was comparably low with CVs between 0.02 and 0.04 . CVs of CPD ranged between 0.04 and 0.11 between animals. CVs of NDFD and ADFD ranged between 0.03 and 0.11 , and between 0.03 and 0.08 , respectively.

The effects of week of lactation, dry matter intake and intake behavior on nutrient digestibility are shown in Table 6. Significant fixed effects $(p<0.05)$ of DMI were found for nutrient digestibility of OM and CP. Week of lactation had a significant effect on CP and $\operatorname{ADFD}(p<0.05)$. Variables of intake behavior had no significant effect on nutrient digestibility. Examination of the components of variance showed that the intercepts significantly varied across cows to the amounts of 50.4, 328.1, 281.1 and 271.4 for OMD, CPD, NDFD and ADFD, respectively. Allowing for all other effects in the model, parameter estimates from this model predicted that nutrient digestibility of $\mathrm{OM}$ and $\mathrm{CP}$ decreased, respectively, by 1.9 (SE 0.68) and 5.2 (SE 1.7) g/ kg DM per kilogram of increase in DMI.

Significant differences could be detected in average and CV values of nutrient digestibility between animals with low mean and high mean feed intake, based on average DMI between week 2 and 15 of lactation of the cows during the trial period, for mean OMD, mean CPD, mean ADF and CV of NDF (Table 7). Mean OMD and CPD in early lactation were significantly higher for animals with mean comparatively low DMI. Mean ADFD and CV of NDFD in early lactation were significantly higher for animals with an average higher DMI. 
Table 6. Influence of week of lactation, dry matter intake and variables of intake behavior on digestibility of OM, CP, NDF and ADF during early lactation in dairy cows, estimated by linear mixed model $(\mathrm{LMM})$ procedure $(n=28)$.

\begin{tabular}{|c|c|c|c|c|c|c|c|c|c|c|c|c|}
\hline \multirow[b]{2}{*}{ Variable } & \multicolumn{3}{|c|}{ OMD } & \multicolumn{3}{|c|}{ CPD } & \multicolumn{3}{|c|}{ NDFD } & \multicolumn{3}{|c|}{ ADFD } \\
\hline & Estimate & SE & $p$-Value & Estimate & SE & $p$-Value & Estimate & SE & $p$-Value & Estimate & SE & $p$-Value \\
\hline Intercept & 754.57 & 11.56 & $<0.01$ & 714.56 & 28.79 & $<0.01$ & 637.31 & 25.25 & $<0.01$ & 600.28 & 19.10 & $<0.01$ \\
\hline Week of lactation & 0.29 & 0.31 & 0.365 & 3.00 & 0.78 & $<0.01$ & 0.39 & 0.68 & 0.561 & -1.75 & 0.51 & $<0.01$ \\
\hline Daily DMI ${ }^{1}$ (kg/day) & -1.83 & 0.68 & 0.008 & -5.15 & 1.70 & 0.003 & -1.95 & 1.49 & 0.194 & -1.34 & 1.15 & 0.244 \\
\hline Meal frequency (meals/day) & -0.06 & 0.22 & 0.787 & 0.11 & 0.53 & 0.831 & 0.09 & 0.47 & 0.836 & -0.17 & 0.36 & 0.650 \\
\hline Meal size $(\mathrm{kg} / \mathrm{meal})$ & 2.92 & 6.16 & 0.636 & -1.29 & 15.37 & 0.933 & 0.63 & 13.56 & 0.963 & 2.24 & 10.44 & 0.830 \\
\hline Feeding time $(\mathrm{min} / \mathrm{d})$ & 0.04 & 0.05 & 0.368 & 0.05 & 0.11 & 0.659 & 0.01 & 0.10 & 0.898 & 0.10 & 0.08 & 0.213 \\
\hline Feeding rate (kg/min) & -0.03 & 0.083 & 0.756 & -0.24 & -0.21 & 0.248 & -0.02 & 0.18 & 0.183 & -0.09 & 0.13 & 0.520 \\
\hline $\mathrm{AIC}^{2}$ & 1508.2 & & & 2150.9 & & & 2055.5 & & & 1849.8 & & \\
\hline
\end{tabular}

${ }^{1}$ Dry matter intake. ${ }^{2}$ Akaike's information criterion. 
Table 7. Mean and CV values of nutrient digestibility of early lactating dairy cows grouped in quartiles according to mean DMI observed between week 2 and 15 of lactation.

\begin{tabular}{|c|c|c|c|c|c|c|c|}
\hline & $\begin{array}{c}\text { Lower Quartile }(<25 \%) \\
(\mathrm{DMI}<18.99 \mathrm{~kg} \mathrm{DMI} / \mathrm{d} \\
\mathrm{n}=7)\end{array}$ & & $\begin{array}{l}\text { Intermediate Quartile } \\
\text { (DMI between } 19.00 \text { and } \\
20.93 \mathrm{~kg} D M I / \mathrm{d}, \mathrm{n}=14 \text { ) }\end{array}$ & & $\begin{array}{c}\text { Upper Quartile } \\
(>75 \%) \\
(\text { DMI }>20.94 \mathrm{~kg} \\
\text { DMI } / \mathrm{d}, \mathrm{n}=7)\end{array}$ & & $p$-Value \\
\hline Mean OMD & 737.08 & $\mathrm{a}$ & 727.17 & $\mathrm{~b}$ & 726.16 & $\mathrm{~b}$ & 0.032 \\
\hline CV OMD & 0.03 & & 0.02 & & 0.03 & & $>0.05$ \\
\hline Mean CPD & 638.98 & $\mathrm{a}$ & 631.20 & $a b$ & 607.60 & $\mathrm{~b}$ & 0.032 \\
\hline CV CPD & 0.07 & & 0.06 & & 0.09 & & $>0.05$ \\
\hline Mean NDFD & 600.85 & & 578.72 & & 583.77 & & $>0.05$ \\
\hline CV NDFD & 0.06 & $\mathrm{a}$ & 0.06 & $\mathrm{a}$ & 0.08 & $\mathrm{~b}$ & 0.006 \\
\hline Mean ADFD & 574.58 & $a b$ & 561.61 & $\mathrm{a}$ & 587.49 & $\mathrm{~b}$ & 0.021 \\
\hline CV ADFD & 0.05 & & 0.06 & & 0.05 & & $>0.05$ \\
\hline
\end{tabular}

\section{Discussion}

Considerable variation was observed between individual animals and within animals over time when examining feed intake, intake behavior and nutrient digestibility. To be able to attribute the variation in the measured parameters to the differences between individual animals, possible confounding factors by breed, feed or environment were reduced to a minimum.

\subsection{Intake Behavior and DMI}

The mean values of dry matter intake and daily feeding time obtained in the current study were within the range, but at the lower end, of results which have been reported in other studies [29-31]. In the present study, daily DMI increased from 14.3 DMI per day in week 2 up to 22.1 in week 11. A similar increase in DMI during early lactation was described by Azizi et al. [31] and Park et al. [32]. In this context, the latter determined a parallel increase in ruminal capacity as a percentage of body weight of $31.2 \%$ during the first 90 days of lactation. DeVries et al. [33] observed an increase in daily mealtime and meal duration from period 1 (35 \pm 16 DIM) to period 2 (57 \pm 16 DIM) as well, but no changes between period 2 and 3 (94 \pm 16 DIM). In contrast, Friggens et al. [34] found no significant effect of the stage of lactation on meal duration and meal size, and likewise, no significant effect of the stage of lactation on meal frequency. However, mean values of meal frequency, meal duration, meal size and feeding rate in the current study were different to the results of other studies [31,35]. A possible explanation for the deviating values may be due to differences in the definition of meal criteria (meals/day). Miron et al. [35], who described an average of 14 meals per day and a meal duration of $15.9 \mathrm{~min} / \mathrm{meal}$, defined a meal as a visit to a trough that lasted at least $1 \mathrm{~min}$ and eating at least $0.2 \mathrm{~kg}$ of TMR. Based on a method developed by Tolkamp et al. [36] and DeVries et al. [33], Azizi et al. [31] calculated a meal criterion of $28.5 \mathrm{~min}$ on average. Variation in the results can be also attributed to differences in methodology (e.g., experimental procedures, diet composition, feeding level). Dado and Allen [30] defined a minimum of $7.5 \mathrm{~min}$ between events to define two eating periods. They reported by early lactating dairy cows (63 DIM) an average of $24.8 \mathrm{~kg}$ DM per day, 10.8 eating bouts per day (meal frequency) with a bout length of 31.1 min (meal duration), a daily feeding time of $314 \mathrm{~min}$ and a meal size of $2.5 \mathrm{~kg}$. Because even the smallest amounts of ingested feed are digested, the definition of meal criteria should be examined more closely, especially in studies which focus on digestibility research.

DMI, meal duration, feeding time and meal size increased over the course of study. In contrast, daily meal frequency and feeding rate remained at the same level during study. The average feeding rate in the present study ( $93.4 \mathrm{~g}$ of DM/min) was lower than reported by others; for example, [37] $120.0 \mathrm{~g}$ of $\mathrm{DM} / \mathrm{min}$, but in agreement with the results shown by Beauchemin et al. [38] (90.0 $\mathrm{g}$ of $\mathrm{DM} / \mathrm{min})$, even though in that study the cows were 
housed in individual tie-stalls without competition between cows. In the current study, cows were housed together with non-experimental cows in a free-stall barn with an animal feeding place ratio of 2:1 and the potential for aggressive interactions and displacements from the feed bunk by other cows existed and, in contrast to Beauchemin et al. [38], no primiparous cows were used in the present study. Albright [7] described, that cows tend to consume more feed at a faster rate when they are fed in groups than when fed separately. In the present study, DMI was significantly influenced by variables of intake behavior. Therefore, intake behavior should be considered when developing strategies to increase feed intake. Grant and Albright [10] concluded that management factors, such as grouping strategy, feeding system design and apparatus, composition and physical characteristics of the feed being consumed, as well as social hierarchy and competition for food and water, are the main factors influencing the intake behavior of cattle, especially for cows with a lower standing in the hierarchy.

All parameters of intake behavior showed a substantial variation between dairy cows at the same stage of lactation and within individual dairy cows during the early lactation. An explanation for the variation between dairy cows at the same stage of lactation may be the different milk yields of the 28 cows. Dado and Allen [30] indicated that cows with higher milk yields achieved greater DMI by increasing meal size and decreasing eating time. Azizi et al. [31] also reported 20\% less eating time and $28 \%$ more DMI in high-yielding dairy cows in comparison to below average yielding cows. Furthermore, higher correlations between intake behavior characteristics and dry matter intake (DMI) within milk yield groups than across all cows were reported [30,34]. Factors which potentially affect the frequency, size and rate of meals could be social interaction between cows [39], feed access [40], palatability and moisture content, as well as the possibility to sort feed, cow health and environmental temperature [39]. No differences, expect a significant lower DMI in second lactating dairy cows, were detected between cows in different parities. Between the categories of low, medium or high dry matter intake, no significant differences in intake behavior parameters and variation were detected, but cows with a higher DMI seemed to be more consistent in intake behavior, except the feeding rate. The high within- and between-cow variability in the current study and in other studies [31,33] indicated that different cows pursue different strategies for nutrient supply. Therefore, it seems even more important to create suitable conditions for the different eating habits to enable high feed intake for all individual cows. Thus, to allow all dairy cows to pursue their own feeding strategy and hence maximize feed intake, the management of young cows should unstintingly focus on designing cow's individual conditions of feed intake. Especially strategies that avoid sorting of feed in heifers at young age, as well as ensuring a balanced nutrient supply via, e.g., TMR, should be considered [41]. However, also ensuring sufficient space and reducing stress by, e.g., avoiding overcrowding, can contribute to a more even feed intake [42]. The assumption of an almost uniform feed intake at the same stage of lactation is misleading and delusive [43].

\subsection{Intake Behavior and Nutrient Digestibility}

Besides feed intake, nutrient digestibility plays an important role for the available nutrient and energy in dairy cattle [9]. The mean between-cow CV in OM digestibility during the trial period was 0.03 . In a recent meta-analysis by Guinguina et al. [44] and in the meta-analysis by Cabezas-Garcia et al. [45], even lower values of 0.014 and 0.013 for between-cow CV in OMD were reported. The results demonstrate that there is little variance among early lactating dairy cows in their ability to digest organic matter of a given diet. In contrast, the variation in digestibility of $\mathrm{CP}, \mathrm{NDF}$ and $\mathrm{ADF}$ with $\mathrm{CV}$ values up to 0.08 between cows at the same stage of lactation was at a higher level. Together with the high intra-individual CV values up to 0.11 of CPD, NDFD and ADFD, the variation challenges the traditional approach of generalizing a uniform feed-digestibility value. By using $\mathrm{iNDF}_{240}$ instead of tabulated digestibility coefficients, it is possible to identify nutrient digestibility at animal level, and thus the level of nutrients available to individual animals, rather than only the feed level of total digestible nutrients (TDN). Therefore, digestibility 
assessed by $\mathrm{iNDF}_{240}$ from a random sample of fecal samples could be used to evaluate the digestibility of the diet, for example, after a change of the diet. Further research is needed to ascertain a robust sample size for determining digestibility within a herd.

The influence of intake behavior on nutrient digestibility is well described for beef cattle in conjunction with feed efficiency. Robinson and Oddy [46] found phenotypic correlations between feed efficiency and the time spent eating and the number of visits to the feeder of 0.64 and 0.51 , respectively. Similar results were reported by Golden et al. [14] and Green et al. [47], who found that efficient cattle ate less and spent less time feeding then inefficient cattle given the same production level. In contrast, research on the influence of intake behavior on nutrient digestibility in dairy cows is rather rare. The presented results do not show any effect of variables of intake behavior on nutrient digestibility but an effect of week of lactation on CPD and ADFD and an effect of dry matter intake on OMD and CPD.

The amount of dry matter consumed and the passage rate are key drivers for the level of digestion, absorption and utilization of feed in the animal. Changes in one of the key drivers lead to changes in the other two [48]. Several researchers have shown that increased intake results in increased passage rates, which is associated with incomplete feed digestion and therefore decreased digestibility [49-51]. Colucci et al. [51,52] reported a close relationship $\left(R^{2}=0.86\right)$ between the decrease in ruminal retention time and depression in digestibility in sheep and cows fed different diets. The effect of higher passage rate is especially distinct when the diet contains a high percentage of fiber. With increasing DMI and an increasing passage rate, fiber cannot be sufficiently digested [9]. The same happens in the first weeks after calving, when DMI increases daily. In the present study, DMI increased up to week 11 p.p. Park et al. [32] also reported a rapid increase in dry matter intake from 2.7 to $4.3 \%$ of body weight between day 6 and 34 postpartum and then a slower increase up to day 81. Parallel to the increase in dry matter intake, a strong increase in ruminal fill was also observed between days 48 and 62 p.p. [32]. Stafford [53] found a decrease in ruminal motility after day 60 p.p., which could reduce the digesta volume flowing from the rumen, increase the ruminal fill, decrease the passage rate and result in increasing digestibility [32]. Furthermore, the model predicted a positive influence of meal duration on OM and ADF to the amounts of 1.57 and $2.91 \mathrm{~g} / \mathrm{kg}$ DM per extra minute of eating time per meal. A possible explanation for the positive influence of meal duration may be the increase in salivary secretion, which reduces the size of feed particles [54] and increases rumen fermentation and nutrient digestibility [55].

Significant differences were detected in mean and inter-individual CV values of nutrient digestibility between animals with a low and a high dry matter intake for OMD, CPD, ADF and CV of NDF. Mean OMD and CPD in early lactation was significantly higher for animals with a lower DMI. Mean ADFD and intra-individual CV of NDFD were significantly higher for animals having on average higher DMI during early lactation. Furthermore, the results indicate differences in fiber digestibility between animals, and challenge the assumption of uniform fiber digestibility for all animals fed the same diet.

\section{Conclusions}

The results of this study show a large variation in intake behavior, feed intake and digestibility as well as interactions between these parameters in early lactating dairy cows. The greater the variation in intake behavior and DMI, the greater the variation in nutrient supply and the proportion of animals that are not adequately supplied with energy and nutrients. Because feed intake and feeding behavior appear to be subject to strong individual influence, it is necessary to consider the interaction at the individual animal level rather than inferring potential relationships via averaged group values in order to reduce the individual animal deficits, especially at the beginning of lactation. The described variation in feed intake behavior shows that animals of the same breed, at the same stage of lactation and in the same environment follow different strategies for nutrient and energy intake. The individuality of the feed intake behavior conflicts with herd-based 
efforts of predicting feed intake. To achieve a sustainable increase in feed intake, and hence nutrient availability, of individual animals, and thus of the herd in the long term, feed conditions must be created that allow for different intake strategies. This includes not only sufficient space at and good access to the feed table, but also a balanced diet and good feeding management. Technical developments that directly assess an individual animal's DMI should be further advanced to enable better future decisions regarding the supply situation of dairy cows. Only by individually increasing the availability or adjusting the output for each animal can long-term improvement in the health status of early lactating cows be achieved.

Author Contributions: Conceptualization, T.R. and A.S.; formal analysis, T.R.; investigation, T.S.; resources, C.K.; data curation, T.R.; writing—original draft preparation, T.R.; writing-review and editing, T.S., C.K. and A.S.; visualization, T.R.; supervision, A.S. All authors have read and agreed to the published version of the manuscript.

Funding: This research received no external funding.

Institutional Review Board Statement: All procedures described in this study were performed according to the German Animal Welfare Act and approved by the local authority for animal welfare affairs (Landesuntersuchungsamt Rheinland-Pfalz; G 18-20-073) in Koblenz, Germany.

Informed Consent Statement: Not applicable.

Data Availability Statement: Not applicable.

Acknowledgments: The authors thank the staff at Educational and Research Centre for Animal Husbandry Hofgut Neumuehle for their assistance during the trial. We are grateful to Regina VickeryGrund for her critical review of the manuscript, and thank Susanne Hartmann, Petra Zahnwetzer and the CVAS team for excellent technical assistance.

Conflicts of Interest: The authors declare no conflict of interest.

\section{Abbreviations}

ADF acid detergent fiber

ADFD digestible acid detergent fiber

aNDFom neutral detergent fiber assayed with heat-stable amylase and expressed exclusive of residual ash

ANOVA analysis of variance

$\mathrm{CP} \quad$ crude protein

CPD digestible crude protein

$\mathrm{CV} \quad$ coefficient of variation

CVAS Cumberland Valley Analytical Services Inc.

DM dry matter

DMI dry matter intake

EE ether extract

ESC ethanol-soluble carbohydrates

GLM generalized linear models

$\mathrm{iNDF}_{240} \quad 240 \mathrm{~h}$ in vitro indigestible neutral detergent fiber

LMM linear mixed model

NDFD digestible neutral detergent fiber

NEL net energy for lactation

NIRS near infrared reflectance spectroscopy

$\mathrm{OM} \quad$ organic matter

OMD digestible organic matter

RIC roughage Intake Control

RSE relative standard error

SD standard deviation

SP soluble protein

TDN total digestibly nutrient

TMR totally mixed ration 


\section{References}

1. Sundrum, A. Metabolic Disorders in the Transition Period Indicate that the Dairy Cows' Ability to Adapt is Overstressed. Animals 2015, 5, 978-1020. [CrossRef]

2. Tremblay, M.; Kammer, M.; Lange, H.; Plattner, S.; Baumgartner, C.; Stegeman, J.A.; Duda, J.; Mansfeld, R.; Döpfer, D. Identifying poor metabolic adaptation during early lactation in dairy cows using cluster analysis. J. Dairy Sci. 2018, 101, 7311-7321. [CrossRef] [PubMed]

3. Ingvartsen, K.L. Feeding-and management-related diseases in the transition cow. Anim. Feed Sci. Technol. 2006, 126, 175-213. [CrossRef]

4. Sordillo, L.M.; Raphael, W. Significance of metabolic stress, lipid mobilization, and inflammation on transition cow disorders. Vet. Clin. N. Am. Food Anim. Pract. 2013, 29, 267-278. [CrossRef] [PubMed]

5. Habel, J.; Sundrum, A. Mismatch of Glucose Allocation between Different Life Functions in the Transition Period of Dairy Cows. Animals 2020, 10, 1028. [CrossRef]

6. Collier, R.J.; Xiao, Y.; Bauman, D.E. Chapter 1-Regulation of Factors Affecting Milk Yield. In Nutrients in Dairy and Their Implications for Health and Disease; Academic Press: Cambridge, MA, USA, 2017; pp. 3-17.

7. Albright, J.L. Feeding Behavior of Dairy Cattle. J. Dairy Sci. 1993, 76, 485-498. [CrossRef]

8. Fish, J.A.; DeVries, T.J. Short communication: Varying dietary dry matter concentration through water addition: Effect on nutrient intake and sorting of dairy cows in late lactation. J. Dairy Sci. 2012, 95, 850-855. [CrossRef]

9. Llonch, P.; Mainau, E.; Ipharraguerre, I.R.; Bargo, F.; Tedó, G.; Blanch, M.; Manteca, X. Chicken or the Egg: The Reciprocal Association Between Feeding Behavior and Animal Welfare and Their Impact on Productivity in Dairy Cows. Front. Vet. Sci. 2018, 5, 305. [CrossRef]

10. Grant, R.J.; Albright, J.L. Feeding behaviour. In Farm Animal Metabolism and Nutrition; D'Mello, J.P.F., Ed.; CABI Publishing: Wallingford, UK, 2000; ISBN 9780851993782.

11. DeVries, T.J.; Keyserlingk, M.V. Time of Feed Delivery Affects the Feeding and Lying Patterns of Dairy Cows. J. Dairy Sci. 2005, 88, 625-631. [CrossRef]

12. Nielsen, B.L. On the interpretation of feeding behaviour measures and the use of feeding rate as an indicator of social constraint. Appl. Anim. Behav. Sci. 1999, 63, 79-91. [CrossRef]

13. Baumont, R.; Malbert, C.H.; Ruckebusch, Y. Mechanical stimulation of rumen fill and alimentary behaviour in sheep. Anim. Sci. 1990, 50, 123-128. [CrossRef]

14. Golden, J.W.; Kerley, M.S.; Kolath, W.H. The relationship of feeding behavior to residual feed intake in crossbred Angus steers fed traditional and no-roughage diets. J. Anim. Sci. 2008, 86, 180-186. [CrossRef]

15. Tyrrell, H.F.; Moe, P.W. Effect of Intake on Digestive Efficiency. J. Dairy Sci. 1975, 58, 1151-1163. [CrossRef]

16. Potts, S.B.; Boerman, J.P.; Lock, A.L.; Allen, M.S.; VandeHaar, M.J. Relationship between residual feed intake and digestibility for lactating Holstein cows fed high and low starch diets. J. Dairy Sci. 2017, 100, 265-278. [CrossRef]

17. NRC. Nutrient Requirements of Dairy Cattle, 7th ed.; National Academies Press: Washington, DC, USA, 2001.

18. AOAC International. Official Methods of Analysis of AOAC International; AOAC International: Gaithersburg, MD, USA, 2006.

19. Krishnamoorthy, U.; Muscato, T.V.; Sniffen, C.J.; van Soest, P.J. Nitrogen Fractions in Selected Feedstuffs. J. Dairy Sci. 1982, 65, 217-225. [CrossRef]

20. van Soest, P.J.; Robertson, J.B.; Lewis, B.A. Methods for Dietary Fiber, Neutral Detergent Fiber, and Nonstarch Polysaccharides in Relation to Animal Nutrition. J. Dairy Sci. 1991, 74, 3583-3597. [CrossRef]

21. Hall, B.M. Neutral Detergent-Soluble Carbohydrates: Nutritional Relevance and Analysis, a Laboratory Manual; University of Florida: Gainesville, FL, USA, 2000.

22. Hall, M.B. Determination of starch, including maltooligosaccharides, in animal feeds: Comparison of methods and a method recommended for AOAC collaborative study. J. AOAC Int. 2009, 92, 42-49. [CrossRef]

23. Raffrenato, E. Physical, Chemical and Kinetic Factors Associated with Fiber Digestibility in Ruminants and Models Describing These Relationships. Ph.D. Thesis, Cornell University, Ithaca, NY, USA, 2011.

24. Althaus, B.; Papke, G.; Sundrum, A. Technical note: Use of near infrared reflectance spectroscopy to assess nitrogen and carbon fractions in dairy cow feces. Anim. Feed Sci. Technol. 2013, 185, 53-59. [CrossRef]

25. Faul, F.; Erdfelder, E.; Lang, A.G.; Buchner, A. G*Power 3: A flexible statistical power analysis program for the social, behavioral, and biomedical sciences. Behav. Res. Methods 2007, 39, 175-191. [CrossRef]

26. Schalla, A.; Meyer, L.; Meyer, Z.; Onetti, S.; Schultz, A.; Goeser, J. Hot topic: Apparent total-tract nutrient digestibilities measured commercially using 120-hour in vitro indigestible neutral detergent fiber as a marker are related to commercial dairy cattle performance. J. Dairy Sci. 2012, 95, 5109-5114. [CrossRef]

27. Girden, E.R. ANOVA: Repeated Measures; Sage Publications: Newbury Park, CA, USA, 2003; ISBN 9780803942578.

28. Dattalo, P. Analysis of Multiple Dependent Variables; Oxford University Press: New York, NY, USA, 2013; ISBN 978-0199773596.

29. Meir, Y.A.B.; Nikbachat, M.; Fortnik, Y.; Jacoby, S.; Levit, H.; Adin, G.; Zinder, M.C.; Shabtay, A.; Gershon, E.; Zachut, M.; et al. Eating behavior, milk production, rumination, and digestibility characteristics of high- and low-efficiency lactating cows fed a low-roughage diet. J. Dairy Sci. 2018, 101, 10973-10984. [CrossRef]

30. Dado, R.G.; Allen, M.S. Variation in and Relationships among Feeding, Chewing, and Drinking Variables for Lactating Dairy Cows. J. Dairy Sci. 1994, 77, 132-144. [CrossRef] 
31. Azizi, O.; Kaufmann, O.; Hasselmann, L. Relationship between feeding behaviour and feed intake of dairy cows depending on their parity and milk yield. Livest. Sci. 2009, 122, 156-161. [CrossRef]

32. Park, A.F.; Shirley, J.E.; Titgemeyer, E.C.; DeFrain, J.M.; Cochran, R.C.; Wickersham, E.E.; Nagaraja, T.G.; Johnson, D.E. Characterization of ruminal dynamics in Holstein dairy cows during the periparturient period. J. Anim. Physiol. Anim. Nutr. 2011, 95, 571-582. [CrossRef]

33. DeVries, T.J.; Keyserlingk, M.V.; Weary, D.M.; Beauchemin, K.A. Measuring the Feeding Behavior of Lactating Dairy Cows in Early to Peak Lactation. J. Dairy Sci. 2003, 86, 3354-3361. [CrossRef]

34. Friggens, N.C.; Nielsen, B.L.; Kyriazakis, I.; Tolkamp, B.J.; Emmans, G.C. Effects of Feed Composition and Stage of Lactation on the Short-term Feeding Behavior of Dairy Cows. J. Dairy Sci. 1998, 81, 3268-3277. [CrossRef]

35. Miron, J.; Yosef, E.; Nikbachat, M.; Zenou, A.; Maltz, E.; Halachmi, I.; Ben-Ghedalia, D. Feeding Behavior and Performance of Dairy Cows Fed Pelleted Nonroughage Fiber Byproducts. J. Dairy Sci. 2004, 87, 1372-1379. [CrossRef]

36. Tolkamp, B.J.; Allcroft, D.J.; Austin, E.J.; Nielsen, B.L.; Kyriazakis, I. Satiety splits feeding behaviour into bouts. J. Theor. Biol. 1998, 194, 235-250. [CrossRef]

37. Hart, K.D.; McBride, B.W.; Duffield, T.F.; DeVries, T.J. Effect of frequency of feed delivery on the behavior and productivity of lactating dairy cows. J. Dairy Sci. 2014, 97, 1713-1724. [CrossRef]

38. Beauchemin, K.A.; Maekawa, M.; Christensen, D.A. Effect of diet and parity on meal patterns of lactating dairy cows. Can. J. Anim. Sci. 2002, 82, 215-223. [CrossRef]

39. Mertens, D.R. Predicting intake and digestibility using mathematical models of ruminal function. J. Anim. Sci. 1987, 64, 1548-1558. [CrossRef] [PubMed]

40. Erdman, R.A.; Moreland, T.W.; Stricklin, W.R. Effect of Time of Feed Access on Intake and Production in Lactating Dairy Cows. J. Dairy Sci. 1989, 72, 1210-1216. [CrossRef]

41. DeVries, T.J.; Keyserlingk, M.A.G.V. Short communication: Feeding method affects the feeding behavior of growing dairy heifers. J. Dairy Sci. 2009, 92, 1161-1168. [CrossRef] [PubMed]

42. Huzzey, J.M.; DeVries, T.J.; Valois, P.; Keyserlingk, M.V. Stocking Density and Feed Barrier Design Affect the Feeding and Social Behavior of Dairy Cattle. J. Dairy Sci. 2006, 89, 126-133. [CrossRef]

43. Jorritsma, R.; Wensing, T.; Kruip, T.A.M.; Vos, P.L.A.M.; Noordhuizen, J.P.T.M. Metabolic changes in early lactation and impaired reproductive performance in dairy cows. Vet. Res. 2003, 34, 11-26. [CrossRef]

44. Guinguina, A.; Yan, T.; Lund, P.; Bayat, A.R.; Hellwing, A.L.F.; Huhtanen, P. Between-cow variation in the components of feed efficiency. J. Dairy Sci. 2020, 103, 7968-7982. [CrossRef]

45. Cabezas-Garcia, E.H.; Krizsan, S.J.; Shingfield, K.J.; Huhtanen, P. Between-cow variation in digestion and rumen fermentation variables associated with methane production. J. Dairy Sci. 2017, 100, 4409-4424. [CrossRef]

46. Robinson, D.L.; Oddy, V.H. Genetic parameters for feed efficiency, fatness, muscle area and feeding behaviour of feedlot finished beef cattle. Livest. Prod. Sci. 2004, 90, 255-270. [CrossRef]

47. Green, T.C.; Jago, J.G.; Macdonald, K.A.; Waghorn, G.C. Relationships between residual feed intake, average daily gain, and feeding behavior in growing dairy heifers. J. Dairy Sci. 2013, 96, 3098-3107. [CrossRef]

48. Colucci, P.E.; Chase, L.E.; van Soest, P.J. Feed Intake, Apparent Diet Digestibility, and Rate of Particulate Passage in Dairy Cattle. J. Dairy Sci. 1982, 65, 1445-1456. [CrossRef]

49. Blaxter, K.L.; Wainman, F.W.; Wilson, R.S. The regulation of food intake by sheep. Anim. Sci. 1961, 3, 51-61. [CrossRef]

50. Huhtanen, P.; Rinne, M.; Nousiainen, J. A meta-analysis of feed digestion in dairy cows. 2. The effects of feeding level and diet composition on digestibility. J. Dairy Sci. 2009, 92, 5031-5042. [CrossRef]

51. Colucci, P.E.; MacLeod, G.K.; Grovum, W.L.; Cahill, L.W.; McMillan, I. Comparative Digestion in Sheep and Cattle Fed Different Forage to Concentrate Ratios at High and Low Intakes. J. Dairy Sci. 1989, 72, 1774-1785. [CrossRef]

52. Colucci, P.E.; MacLeod, G.K.; Grovum, W.L.; McMillan, I.; Barney, D.J. Digesta Kinetics in Sheep and Cattle Fed Diets with Different Forage to Concentrate Ratios at High and Low Intakes. J. Dairy Sci. 1990, 73, 2143-2156. [CrossRef]

53. Stafford, K.J. Ruminoreticular motility in ewes during pregnancy and lactation. J. Vet. Med. 1991, 38, 798-800. [CrossRef]

54. Beauchemin, K.A.; Eriksen, L.; Nørgaard, P.; Rode, L.M. Short communication: Salivary secretion during meals in lactating dairy cattle. J. Dairy Sci. 2008, 91, 2077-2081. [CrossRef]

55. Aikman, P.C.; Reynolds, C.K.; Beever, D.E. Diet digestibility, rate of passage, and eating and rumination behavior of Jersey and Holstein cows. J. Dairy Sci. 2008, 91, 1103-1114. [CrossRef] 